Jurnal Kejuruteraan SI 1(1) 2018: 47-57

http://dx.doi.org/10.17576/jkukm-2018-si1(1)-07

\title{
Enhanced Biogas Production from Agro Wastes by Co-digestion with Crude Glycerol
}

\author{
(Peningkatan Penghasilan Biogas daripada Sisa Agro melalui Pencernaan Bersama dengan Gliserol) \\ Siti Kartom Kamarudin, ${ }^{\mathrm{a}, \mathrm{b},}$, Anitha a/1 Muniandy ${ }^{\mathrm{b}}$, Noor Shahirah Shamsul ${ }^{\mathrm{b}}$, Hisham Tan Kofli ${ }^{\mathrm{b}}$ \\ ${ }^{a}$ Fuel Cell Institute \\ ${ }^{b}$ Department of Chemical Engineering, Faculty of Engineering \& Built Environment \\ Universiti Kebangsaan Malaysia, Malaysia
}

\begin{abstract}
Excessive of agro wastes and crude glycerol required efficient management in order to avoid environmental pollution. Varieties of elements content in agro wastes and crude glycerol highly potential to become feedstock for production of biogas. The objective of this study was to investigate the improvement of biogas production by anaerobic co-digestion of agro wastes with crude glycerol. Sugarcane bagasse, dried leaves, corn stover, cattle manure and crude glycerol were used in production of biogas using anaerobic co-digestion method conducted at room temperature, $p H$ 6.8-7.2 for 30 days in $2 L$ of bio-reactor. The contain of crude glycerol was determined by Gas Chromatography Mass Spectrometer (GC-MS) while the present of bio-methane was analysed by Gas Chromatography Thermal Conductively Detector (GC-TCD). Meanwhile the bio-ethanol formed was detected by High Performance Liquid Chromatography (HPLC). Mixture of cattle manure, sugarcane bagasse, and crude glycerol content of highest $\mathrm{C} / \mathrm{N}$ ratio (22.42) while co-digestion of these samples produced 20L biogas $g^{-1}$ VS added. Meanwhile about 33.07\% to 42.27\% COD removal obtained in Experiment 1 while $27.86 \%$ to $45.52 \%$ COD removal obtained in Experiment 2. Co-digestion of cattle manure and sugarcane bagasse with crude glycerol produced 3.2 L biogas $\mathrm{g}^{-1} \mathrm{VS}$ added. About $0.28 \mathrm{mg} / \mathrm{L}$ of acetic acids detected at day 20 in Experiment 1 while $0.28 \mathrm{mg} / \mathrm{L}$ of acetic acids detected in day 15 in Experiment 2. Therefore, this study proof that the co-digestion of cattle manure, agricultural wastes and crude glycerol resulted in higher biogas yields.
\end{abstract}

Keywords: Biogas; Methane; Glycerol; Agro Waste; Co-Digestion

ABSTRAK

Lambakkan sisa agro dan gliserol mentah memerlukan pengurusan yang cekap untuk mengelakkan pencemaran alam sekitar. Kepelbagaian unsur yang terkandung dalam sisa agro dan gliserol mentah berpotensi untuk menjadi bahan mentah untuk penghasilan biogas. Objektif kajian ini adalah untuk mengkaji peningkatan penghasilan biogas oleh ko-pencernaan anaerobik sisa agro dengan gliserol mentah. Hampas tebu, daun kering, sisa jagung, najis lembu dan gliserol mentah digunakan dalam penghasilan biogas menggunakan kaedah pencernaan anaerobik yang dijalankan pada suhu bilik, $p H$ 6.8-7.2 selama 30 hari dalam bio-reaktor 2L. Kandungan gliserol mentah ditentukan oleh Kromotografi Gas Spektrometrik Jisim (GC-MS) sementara biogas kini dianalisis oleh pengesan konduktiviti kromatografi gas (TCD). Asid lemak tidak menentu yang terbentuk dikesan oleh Kromatografi Cecair Prestasi Tinggi (HPLC). Campuran najis lembu, hampas tebu, sisa jagung dan gliserol mentah mengandungi nisbah C/N tertinggi (22.42) manakala pencernaan sampel ini menghasilkan 20L biogas g-1 VS ditambah. Sementara itu sebanyak $33.07 \%$ hingga $42.27 \%$ COD tersingkir diperoleh dalam Eksperimen 1 manakala sebanyak $27.86 \%$ hingga $45.52 \%$ COD tersingkir diperoleh dalam Eksperimen 1. Ko-pencernaan najis lembu dan hampas tebu dengan gliserol mentah menghasilkan $3.2 \mathrm{~L}$ biogas $\mathrm{g}-1 \mathrm{VS}$ ditambah. Sebanyak $0.28 \mathrm{mg} / \mathrm{L}$ asid asetik dikesan pada hari ke 20 dalam Eksperimen 1 manakala $20 \mathrm{mg} / \mathrm{L}$ asid asetik dikesan pada hari ke 15 dalam Eksperimen 2. Oleh itu, kajian ini membuktikan bahawa pencernaan najis lembu, sisa pertanian dan gliserol mentah menghasilkan produk biogas yang lebih tinggi.

Kata kunci: Biogas; Metana; Gliserol; Sisa agro; Ko-pencernaan

\section{INTRODUCTION}

Depletion of fossil fuels, high demand for energy and increased of greenhouse gases concentration encourage rapid growth of biodiesel industry in the last few decades (Madzaki et al. 2018). Note that for every $100 \mathrm{~kg}$ of biodiesel production, approximately $10 \mathrm{~kg}$ of glycerol formed (Hazimah et al. 2003; Anitha et al. 2016; Almeida et al. 2012). Excessive of glycerol formation due to commercialization of biodiesel production for industry and transportation caused reduction in glycerol economic value (Yazdani et al. 2007; Fernando et al. 2007; Bournay et al. 2005; Ramadhas et al. 2005). Hence, it is suggested to utilize and recycle the glycerol produced to become valuable renewable energy (Ayoub \& Abdullah 2012). 
Approximately 5 billion metric tons of agro wastes are generated annually, which is equivalent to 1.2 billion tons of oil (UNEP 2011). The correct management of agro wastes can be an effective approach to recover the high energy value of these wastes. Anaerobic digestion is a distinguished and resourceful process to turn agro wastes such as agricultural residues, livestock wastes and municipal solid waste into renewable fuel, i.e. biogas (Wei et al. 2014; Liu et al. 2015). Degradation of agro waste involve in four stages, including hydrolysis, acidogenesis, acetogenesis and methanogenesis (Yuzir et al. 2012). Hydrolysis is a process by which complex organic molecules are broken down into simpler monomers. Meanwhile acidogenesis reaction will convert simpler monomers become volatile fatty acids. After that the volatile fatty acids, methanol and ethanol are subsequently consumed by the acetogenic bacteria and then converted them become acetic acid, hydrogen and carbon dioxide. Last stage (methanogenesis) occurs when methanogens quickly convert the readily available products (volatile fatty acids, methanol and ethanol) into methane and carbon dioxide (biogas) (Goswami et al 2007; Mata-Alvarez 2003; Gavala et al. 2003).

Astals et al. (2012) claimed that anaerobic co-digestion could be greatly improved by glycerol and animal manure mixture due to high moisture content in the manure acts as a solvent for glycerol. Mata-Alvarez et al. (2011) state that glycerol contribute in facilitate decomposable matter during anaerobic digestion. Robra et al. (2010) found that biodieselderived crude glycerol is a potential source of carbon for anaerobic digestion with cattle manure. Experiments conducted by Siles López et al. (2009) showed that pretreated crude glycerol derived from biodiesel manufacturing increases methane production and anaerobic biodegradability. Rivero et al. (2014) studied the anaerobic co-digestion of crude glycerol derived from the biodiesel industry and mixed sewage sludge from wastewater treatment plants in mesophilic conditions result in improvement of bio-hydrogen and biomethane yields, with an $89 \%$ removal of volatile solids and a 93\% removal of COD. A study conducted by Tokumoto and Kashiwagi (2012) revealed that the high loading of glycerol in the presence of glucose promotes hydrogen generation by amending the microbial population of dominant species. Watanabe et al. (2013) reported that Japanese cedar charcoal is useful for the anaerobic digestion of glycerol allows microbes to attach to charcoal, thus improving methane production. Panpong et al. (2013) obtained a maximum methane yield was $577 \mathrm{mLCH} 4 / \mathrm{g}$ VS-added and 97\% biodegradability by anaerobic co-digestion of $99 \%$ can seafood wastewater with $1 \%$ glycerol while anaerobic digestion of can seafood wastewater only (without addition of glycerol) produced $278 \mathrm{mLCH} 4 / \mathrm{g} \mathrm{VS}$-added. Fountoulakis and Manios (2009) claimed that by adding $1 \% \mathrm{v} / \mathrm{v}$ crude glycerol to the feed (organic municipal solid wastes), the methane production rate increased from $479 \mathrm{~mL} / \mathrm{d}$ to $1210 \mathrm{~mL} / \mathrm{d}$.

Therefore the objectives of this work were to evaluate the use of glycerol as a co-substrate, to improve biogas production by anaerobic co-digestion of agro wastes: the cattle manure and agricultural wastes (sugarcane bagasse, dried leaves and corn stover) mixture. Meanwhile the effect of crude glycerol on the anaerobic digestion process was assessed by carrying out two experiments with and without the addition of crude glycerol in single bioreactor.

\section{METHODOLOGY}

SAMPLES PREPARATION

Dried leaves, corn stover and sugarcane bagasse were chosen as agricultural wastes for this study. Crude glycerol, agricultural wastes and cattle manure were obtained from Jenderam Hilir farm at Dengkil Selangor. Agricultural wastes were dried in an air oven (model Thermo UT 6200, Germany) at $45^{\circ} \mathrm{C}$ for 48 to 72 hours until the moisture content was less than $10 \mathrm{wt} . \%$. Then the agro wastes were grounded using a universal cutting mill (PULVERISETTE 19, Germany) to reduce the particle size from $10 \mathrm{~mm}$ to become $2 \mathrm{~mm}$. The crude glycerol feedstock from the fatty alcohol manufacturing process was used as a co-substrate while cattle manure acted as an inoculum.

\section{BATCH ANAEROBIC DIGESTION}

Anaerobic digestion in a batch-scale reactor was carried out in duplicate, using 2-litre Duran bottles with two sampling ports at an ambient temperature in the range of $25-28^{\circ} \mathrm{C}$. Two sets of experiments were run to monitor the performance of the anaerobic digestion, with and without the addition of crude glycerol (Experiments 1 and 2, respectively). Each reactor was filled with $400 \mathrm{~g}$ of cattle manure (dry weight basis) and agricultural wastes were then added into the reactor, based on the inoculum-to-substrate ratio of $2 / 1$. The amount of feedstock added to the reactor was calculated based on the value of total solids (TS). Distilled water was added until a 2-8 wt. $\%$ of total solid was obtained. Next, about $1 \% \mathrm{v} / \mathrm{w}$ of crude glycerol was added to each reactor and the initial $\mathrm{pH}$ of the samples was adjusted to be in the range of 6.8-7.2. A reactor with inoculum and crude glycerol were run as the control for Experiment 1, and a reactor with only inoculum was run as the control for Experiment 2. The reactors were then purged with nitrogen gas to create anaerobic conditions while the volume of biogas was measured using the water displacement method and was recorded daily, subject to biogas production.

\section{ANALYTICAL METHOD}

The three types of wastes were characterized, and the performance of the reactors was monitored by tracking their $\mathrm{pH}$, chemical oxygen demand (COD), total solids (TS), volatile solids, total alkalinity, total volatile acids (VFA) and total carbohydrates. The $\mathrm{pH}$ value was measured using a pH-meter (Metrohm 827 pH Lab, Switzerland). The COD was determined using the HACH reactor digestion method (Method 8000). Total solids and volatile solids of the samples were 
determined based on ASTM E1759-08 (E1759-08 2008) and ASTM E897-88 (E897-88 2004), respectively. Total alkalinity and total volatile acids were determined based on Methods 2320B and 2310B, respectively, from Standard Methods for the Examination of Water and Wastewater (APHA 1999). Total carbohydrates were measured by a colorimetric method at UV $490 \mathrm{~nm}$, using glucose as a standard (Zhou et al. 2013).

The glycerol content of crude glycerol was measured on an Agilent 7890A gas chromatograph directly coupled to the mass spectrometer system of an Agilent 5975C inert MSD with a triple-axis detector, equipped with a DB-5ms UI column ( $5 \%$ phenyl methyl polysiloxane, $30 \times 0.25 \mathrm{~mm} \times$ $0.25 \mu \mathrm{m})$. All the peaks in the raw GC chromatogram were obtained from the MSD Chemstation, and the components were identified using the NIST/EPA/NIH library, version 2.0. The elemental compositions of the samples were analysed using a CHNS analyser, and the analysis was performed by the Malaysian Nuclear Agency in Bangi, Selangor.

The acetic acid and ethanol concentrations were determined by high-performance liquid chromatography (HPLC) (Agilent 1200, USA), with a refractive index detector. The samples were centrifuged at $8000 \mathrm{rpm}$ for 30 minutes, and the supernatant was stored at $-20^{\circ} \mathrm{C}$ until HPLC analysis. Prior to the analysis, the samples were filtered through 0.45 $\mu \mathrm{m}$ Whattman GD/X syringe filters directly into the HPLC vials. Standard calibration curves were plotted using 5 different concentrations of acetic acid (HmBG Chemicals, Germany) and ethanol (HmBG Chemicals, Germany). The analysis was performed on an HPLC ion-exclusion column, Rezex ROAOrganic Acid $\mathrm{H}+(8 \%), 30 \times 4.6 \mathrm{~mm}$, heated to $60^{\circ} \mathrm{C}$, and $0.005 \mathrm{~N} \mathrm{H} 2 \mathrm{SO} 4$ was used as the mobile phase at a flow rate of $0.6 \mathrm{~mL} / \mathrm{min}$. The biogas composition was analysed by gas chromatography (SRI-GC 8610C), with a molecular sieve 5A column connected to a thermal conductivity detector (TCD) and with helium as the carrier gas.

\section{RESULT AND DISCUSSION}

\section{CHARACTERISTIC OF SUBSTRATE AND INOCULUM}

Characteristics of the agro waste samples and inoculums used were shown in Table 1. Sugarcane bagasse had the highest total solid was from corn stover $(91.06 \mathrm{wt} \%)$ while highest volatile solid was from sugarcane bagasse (98 wt.\%). High value of total solid with a low moisture content which typically $(<50 \%)$ illustrates the efficiencies of the biomass sources for thermal conversion to liquid fuels.

Note that the significance of the volatile solids and fixed solids contents provide a measure of the ease with which the biomass can be ignited and subsequently gasified or oxidized, depending on how the biomass is to be utilized as an energy source. Higher volatile solids content of sugarcane bagasse (98.34 wt\%) compared with the other wastes indicates the potential amount of solid transformed into other products, either in the liquid or gas phase.
TABLE 1. Displays the characteristics of samples

\begin{tabular}{lrrrr}
\hline Parameter & $\begin{array}{c}\text { Dried } \\
\text { leaves }\end{array}$ & $\begin{array}{l}\text { Corn } \\
\text { stover }\end{array}$ & $\begin{array}{l}\text { Sugarcane } \\
\text { bagasse }\end{array}$ & $\begin{array}{c}\text { Cattle } \\
\text { manure }\end{array}$ \\
& 90.25 & 91.06 & 90.82 & 27.99 \\
Total solids (wt.\%) & 92.61 & 96.32 & 98.34 & 87.47 \\
Volatile solids (wt.\%) & 7.39 & 3.68 & 1.66 & 12.53 \\
Fixed solids (wt.\%) & 9.75 & 8.94 & 9.18 & 72.01 \\
Moisture content (wt.\%) & 5.41 & 3.95 & 1.66 & 14.15 \\
Ash (wt.\%) & $\mathrm{ND}$ & $\mathrm{ND}$ & $\mathrm{ND}$ & 2270 \\
sCOD (mg/L) & & & & \\
Ammonia-nitrogen & $\mathrm{ND}$ & $\mathrm{ND}$ & $\mathrm{ND}$ & 96.9 \\
(mg/L) & 11.10 & 4.40 & 19.33 & 0.41 \\
$\mathrm{Concentration}$ of anions $(\mathrm{ppm})$ & - & 51.36 & 2.20 & - \\
$\mathrm{F}^{-}$ & 105.12 & 141.20 & 30.92 & 323.52 \\
$\mathrm{Br}^{-}$ & - & 5.43 & 1.40 & - \\
$\mathrm{Cl}^{-}$ & - & - & - & 2.51 \\
$\mathrm{NO}_{3}^{-}$ & 47.92 & 44.24 & 10.62 & 18.52 \\
$\mathrm{NO}_{2}^{-}$ & 4.72 & 45.51 & 5.65 & 15.05 \\
$\mathrm{SO}_{4}^{2-}$ & 65.31 & 47.71 & 37.85 & 90.26 \\
$\mathrm{PO}_{3}^{-}$ & 51.39 & 139.55 & 37.85 & 323.59 \\
$\mathrm{Concentration} \mathrm{of} \mathrm{cations}^{-}(\mathrm{ppm})$ & & & \\
$\mathrm{Na}^{+}$ & 21.54 & 33.62 & 15.59 & 34.28 \\
$\mathrm{~K}^{+}$ & 10.75 & 6.38 & 8.99 & 54.37 \\
$\mathrm{Mg}^{2+}$ & 2.51 & 4.72 & 4.95 & 38.47 \\
$\mathrm{Ca}^{2+}$ & & & & \\
$\mathrm{NH}_{4}^{+}$ & & & & \\
\hline
\end{tabular}

*ND - not determined

Meanwhile the total COD of cattle manure was 2270 $\mathrm{mg} / \mathrm{L}$, and the concentration of ammonia-nitrogen was 96.9 $\mathrm{mg} / \mathrm{L}$. According to ionic chromatography analysis, it was found that highest concentrations of sodium $\left(\mathrm{Na}^{+}\right)$, potassium $\left(\mathrm{K}^{+}\right)$, magnesium $\left(\mathrm{Mg}^{2+}\right)$, calcium $\left(\mathrm{Ca}^{2+}\right)$ and ammonia $\left(\mathrm{NH}_{4}^{+}\right)$ were present in cattle manure compare to other agricultural waste biomass samples. Based on elemental compositions analysis of samples in Table 2, the carbon content of the dried leaves was the highest (45 wt.\%), followed by sugarcane bagasse (42 wt.\%), corn stover (41 wt.\%) and cattle manure (39 wt.\%). Value of $\mathrm{C} / \mathrm{N}$ ratios of every sample in the influents for Experiments 1 and 2 illustrated in Table 3 and it can be observed the addition of crude glycerol increased the $\mathrm{C} / \mathrm{N}$ ratio of the influent.

TABLE 2. Elemental compositions of the samples

\begin{tabular}{lcccc}
\hline Samples & C (\%) & H (\%) & N (\%) & S (\%) \\
\hline $\begin{array}{l}\text { Dried leaves } \\
\text { Cornstover }\end{array}$ & $45.1 \pm 2.1$ & $6.65 \pm 0.15$ & $2.15 \pm 0.65$ & $0.21 \pm 0.06$ \\
Sugarcane & & & & \\
bagasse & $42.1 \pm 0.5$ & $6.08 \pm 0.15$ & $1.31 \pm 0.23$ & $0.07 \pm 0.02$ \\
Cattle manure & $38.5 \pm 1.7$ & $5.61 \pm 0.51$ & $3.59 \pm 0.54$ & $0.48 \pm 0.03$ \\
Crude glycerol & $33.5 \pm 1.4$ & $11.7 \pm 0.9$ & $0.19 \pm 0.09$ & $<0.05$ \\
\hline
\end{tabular}


TABLE 3. $\mathrm{C} / \mathrm{N}$ ratios of samples

\begin{tabular}{lc}
\hline \multicolumn{1}{c}{ Sample } & $\begin{array}{c}\text { C/N ratio of } \\
\text { the influent }\end{array}$ \\
\hline $\begin{array}{l}\text { Experiment 1 } \\
\text { Dried leaves + Cattle manure + Crude glycerol }\end{array}$ & 19.78 \\
Corn stover + Cattle manure + Crude glycerol & 18.74 \\
Sugarcane bagasse + Cattle manure + & \\
Crude glycerol & 22.42 \\
Cattle manure + Crude glycerol & 19.05 \\
Experiment 2 & \\
Dried leaves + Cattle manure & 14.60 \\
Corn stover + Cattle manure & 13.61 \\
Sugarcane bagasse + Cattle manure & 16.45 \\
Cattle manure & 10.72 \\
\hline
\end{tabular}

Sugarcane bagasse-cattle manure-crude glycerol in Experiment 1 and sugarcane-cattle manure in Experiment 2 has higher $\mathrm{C} / \mathrm{N}$ ratios of 22 and 16, respectively. High contents of $\mathrm{C}$ and $\mathrm{H}$ contribute to the high $\mathrm{C}: \mathrm{H}$ ratio, indicating that the large amounts of both elements present in the waste are suitable for obtaining bio-fuel characteristics.

Characteristic of crude glycerol that used as the cosubstrate in anaerobic co-digestion of agro waste and cattle manure can be seen in Table 4. High carbon content of $34 \%$ $\mathrm{w} / \mathrm{w}$ in the crude glycerol is believed to act as an extra carbon source. Ion chromatographic analysis of crude glycerol showed that chloride $\left(\mathrm{Cl}^{-}\right)$, fluoride $\left(\mathrm{F}^{-}\right)$and ammonium $\left(\mathrm{NH}_{4}^{+}\right)$ions were present at higher concentrations in crude glycerol. The glycerol content in the sample crude glycerol was $87.27 \% \mathrm{w} / \mathrm{w}$.

TABLE 4. Characteristics of crude glycerol

\begin{tabular}{|c|c|}
\hline Parameter & Value \\
\hline $\mathrm{pH}$ & 11.76 \\
\hline pH (diluted 1000 times) & 5.79 \\
\hline Color & Brown \\
\hline Refractive index at $27.6^{\circ} \mathrm{C}$ & 1.467 \\
\hline Ash content (wt.\%) & 0.65 \\
\hline Total COD $(g / L)$ & 751 \\
\hline Total free alkali, as $\mathrm{Na}_{2} \mathrm{O}$, wt.\% & 0.298 \\
\hline Total free acid, as $\mathrm{Na}_{2} \mathrm{O}$ equivalent, wt. $\%$ & 0 \\
\hline Moisture content, Loss on drying wt.\% & 4.80 \\
\hline Glycerol content $\% \mathrm{w} / \mathrm{w}$ & 87.27 \\
\hline \multicolumn{2}{|l|}{ Concentration of anions (ppm) } \\
\hline $\mathrm{F}^{-}$ & 18.79 \\
\hline $\mathrm{Cl}^{-}$ & 43.85 \\
\hline $\mathrm{NO}_{2}^{-}$ & 12.53 \\
\hline $\mathrm{SO}_{4}^{2-}$ & 0.84 \\
\hline \multicolumn{2}{|l|}{ Concentration of cations (ppm) } \\
\hline $\mathrm{K}^{+}$ & 6.23 \\
\hline $\mathrm{Ca}^{2+}$ & 2.08 \\
\hline $\mathrm{NH}_{4}^{+}$ & 1187.52 \\
\hline
\end{tabular}

PH VARIATION, SOLUBLE COD, TOTAL SOLIDS (TS) AND VOLATILE SOLIDS (VS) AND TOTAL ALKALINITY

Result of Experiment 1 and Experiment 2 in Figure 1 illustrated the $\mathrm{pH}$ of every samples in the reactors varied ( 5 to 7.5 ) from 0 to 30 days. Value of $\mathrm{pH}$ of the reactors fluctuated rapidly throughout the experiment due to varieties in elements composition (CHNSO) and complex carbohydrate chain contain in every agro wastes. In order to regulate the $\mathrm{pH}$ of the reactors, about $5 \mathrm{~N} \mathrm{NaOH}$ and $3 \mathrm{~N} \mathrm{HCl}$ solutions were used. In the initial stage of anaerobic digestion (hydrolysis phase), complex molecules were degraded into smaller and simple sugars, which were then consumed by the acidforming bacteria to be reduced into volatile acids, small-chain alcohols and other compounds. Note that methanogens were active in alkali environment, unfortunately their activity tended to reduce when the $\mathrm{pH}$ was below 6.5 (minimum 6.0) (Strik et al. 2006).
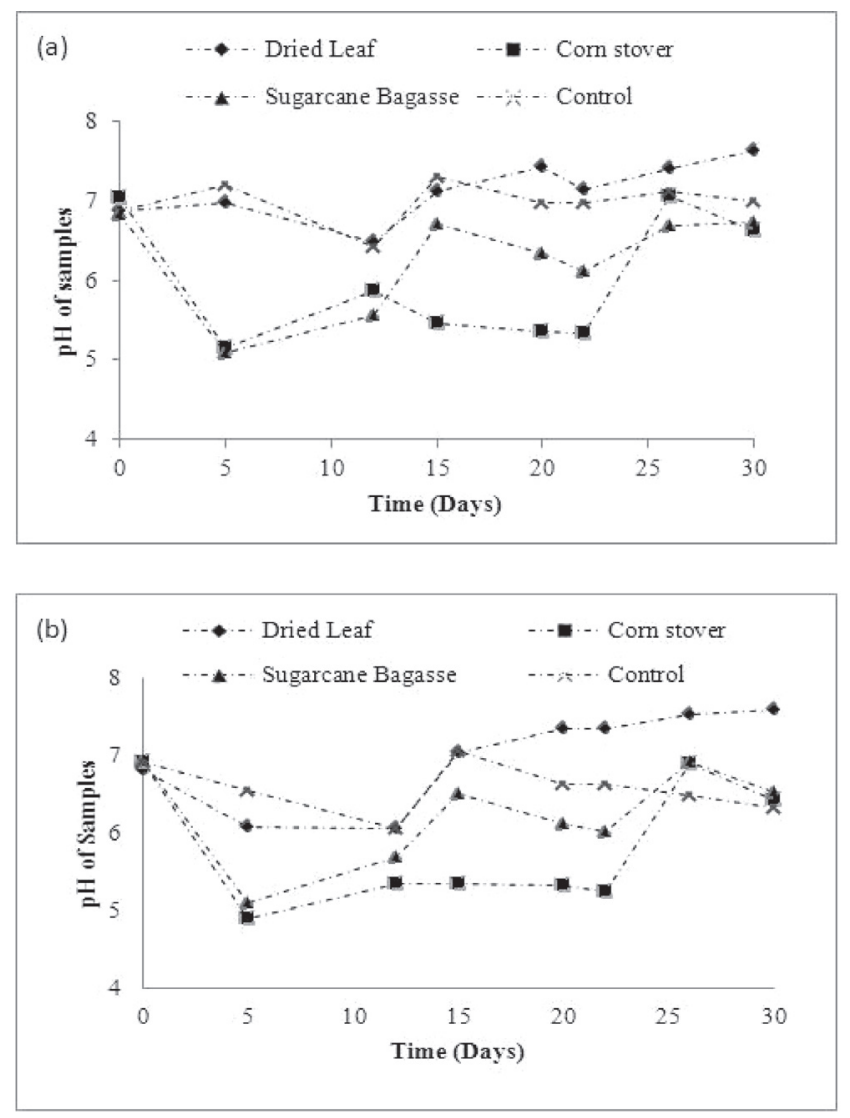

FIGURE 1. pH of samples (a) Experiment 1 (b) Experiment 2

Value of COD was determined to indicate the organic strength of the digestate of each reactor for 30 days as shown in Figure 2. The initial sCOD values for dried leaves, corn stover, sugarcane bagasse and the control for Experiment 1 were $131 \mathrm{~g} / \mathrm{L}, 158 \mathrm{~g} / \mathrm{L}, 92 \mathrm{~g} / \mathrm{L}$, and $97 \mathrm{~g} / \mathrm{L}$, respectively. Meanwhile for Experiment 2, the initial SCOD values were $149 \mathrm{~g} / \mathrm{L}, 116 \mathrm{~g} / \mathrm{L}, 132 \mathrm{~g} / \mathrm{L}$ and $118 \mathrm{~g} / \mathrm{L}$ for dried leaves, corn stover, sugarcane bagasse and the control, respectively. The COD removal for dried leaves, corn stover, sugarcane bagasse 
and control reactors in Experiment 1 was 36.46\%, 42.27\%, $33.07 \%$ and $9.22 \%$, respectively. On the other hand, the COD removal of dried leaves, corn stover, sugarcane bagasse and control reactors of Experiment 2 was $27.86 \%, 45.52 \%$, $34.78 \%$ and $55.76 \%$, respectively. At the beginning of the experiment, the SCOD value increased steadily and then diminished gradually as the microbes consumed the organic components (Macias-Corral et al. 2008). It can be seen in Figure 2 the COD removal were higher in Experiment 2 than Experiment 1 due to extra carbon sources in Experiment 1 (glycerol) caused in slow methanogens activity in the methanogenesis stage. Moreover the varied viscosity of inoculum and substrates in the bioreactor during 30 days digestion contribute in unstable and reduced methanogen activity.
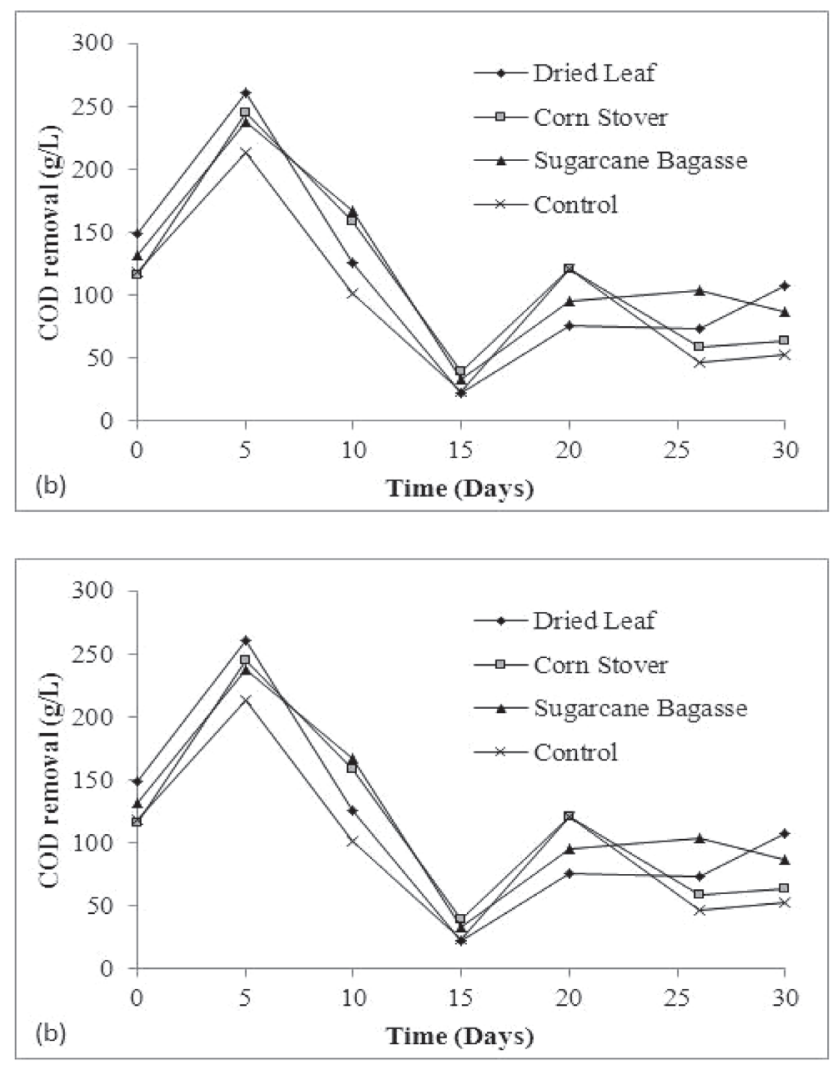

FIGURE 2. Soluble COD concentration (a) Experiment 1 (b) Experiment 2

Value of total solids and volatile solids for Experiments 1 and 2 are shown in Figure 3. The influents were fed when the TS was 2-8\%; as the reaction proceeded, the TS increased, and the digestate liquor became semi-solid. Abbasi-Guendouz et al. (2012) discovered that at higher TS, methane production decreased and was inhibited at $35 \% \mathrm{TS}$, and the hydrolysis rate constants reduced as TS increased. The percentage of volatile solids represents the fraction of total solids that are organic and biodegradable, and the varying degree of consumption of this measurable is a crucial factor determining the rate of gas production (Mital 1997). Figure 3(b) and 3(d) show a decreasing trend in the VS. Furthermore, the reduction of vs is expected to increase if the retention time is prolonged.
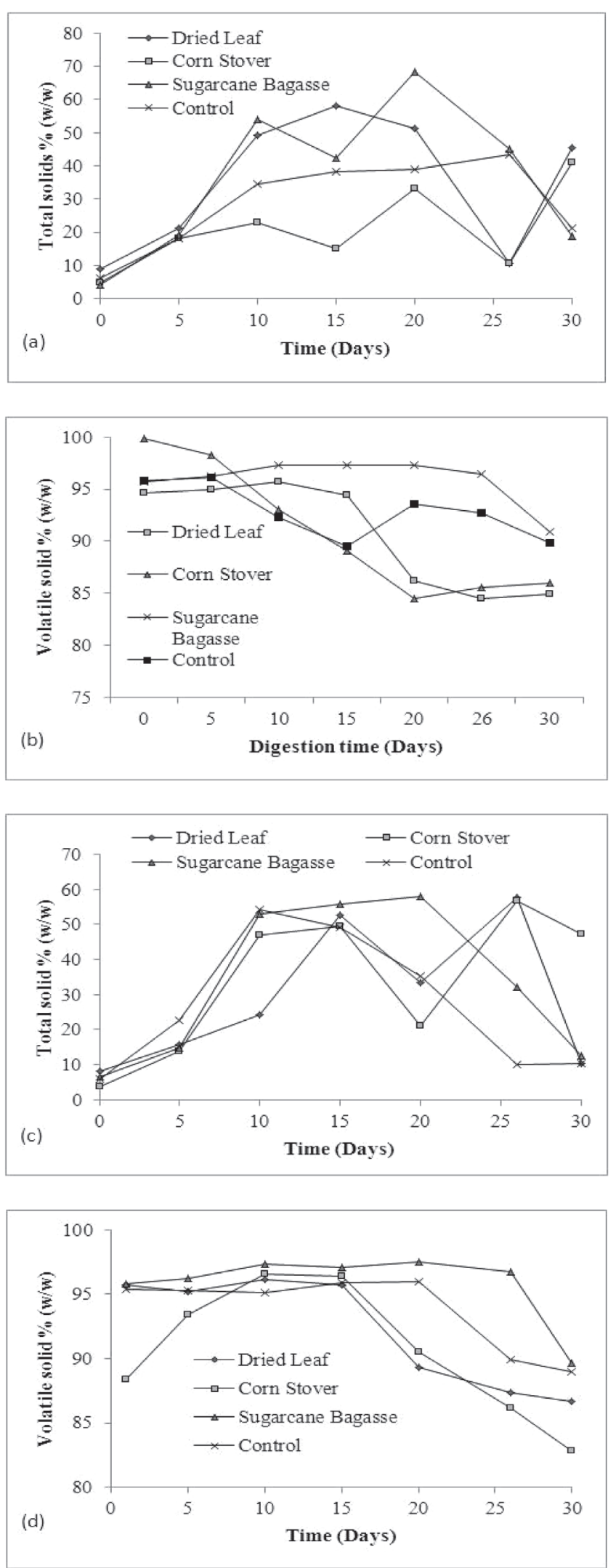

FIGURE 3. Total solids and volatile solids (a-b) Experiment 1 (c-d) Experiment 2 
VS removal for dried leaves, corn stover, sugarcane bagasse and control reactors in Experiment 1 was 10.28\%, $13.98 \%, 5.02 \%$ and $6.26 \%$, respectively. On the other hand, VS removal for dried leaves, corn stover, sugarcane bagasse and control reactors of Experiment 2 was $9.45 \%, 6.27 \%$, $6.48 \%$ and $6.67 \%$, respectively.

The alkalinity value shows the buffering capacity of the reactor to neutralize acids produced by the acidogenic bacteria. Both of Experiment 1 and Experiment 2 samples have same trend of total alkalinity as illustrated in Figure 4. After 5 days of co-digestion, the total alkalinity of the mixture drastically increased until days 25 , the value of total alkalinity decreased. This may happened due digestion stability and the ability to resist $\mathrm{pH}$ changes. It is important to maintain the alkalinity environment during anaerobic co-digestion so that the activity of methanogens will not reduce for production of biogas and volatile fatty acids in bioreactor.
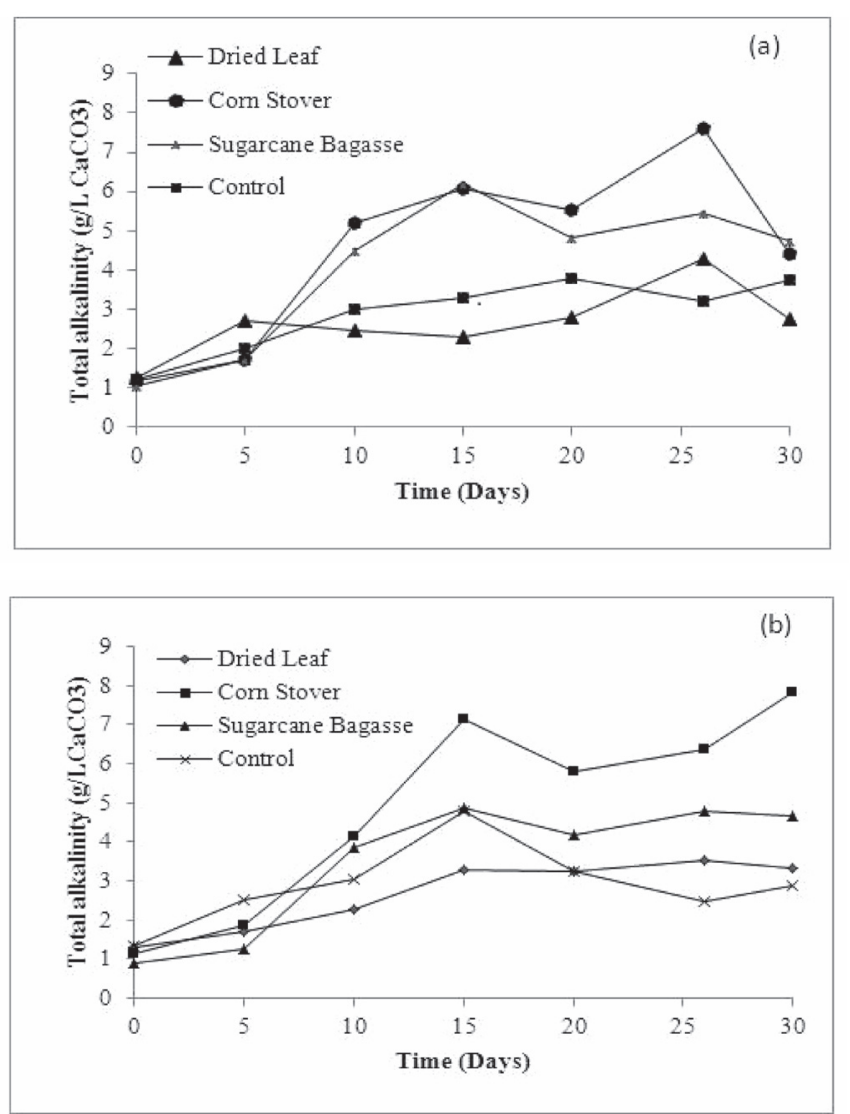

FIGURE 4. Total alkalinity of the samples (a) Experiment 1 (b) Experiment 2

TOTAL CARBOHYDRATE, VFA DEGRADATION AND ETHANOL CONCENTRATION

Analysis on total carbohydrates in the influent fed into the reactors and in the effluent at the end of the $30^{\text {th }}$ day prove the effectiveness of co-digestion method to convert carbohydrate become liquid (volatile fatty acids) and gas product (biogas). From the Table 5, the total carbohydrates in each reactor were reduced and consumed in the reaction by the end of the experiment. It can be seen that sugarcane bagasse has high carbohydrate content available for digestion (18.11 g/L), compared to other substrates (Table 5). On that account, it is expected that $96 \%$ of total carbohydrate digested in the bioreactor by co-digestion of sugarcane bagasse to become bio-liquid, biogas and solid products.

Volatile acids are the intermediate products of the anaerobic digestion process, formed during acidogenesis (DROSG 2013). Figure 5(a) and 5(c) display the total volatile acids accumulated in the reactors throughout the experimental period. It can be observed that VFA production showed an increasing trend for the first 10 to 15 days and then reduced slightly and fluctuated with further progress of the reaction. It can be concluded that during the initial phase of anaerobic digestion, the microbes actively degraded complex molecules into VFAs, and the acids accumulated in the reactors. Generally, the accumulation of VFAs indicates the relationship between the producers and consumers of acids; as a result, the methanogenesis process is inhibited (Ahring el al. 1995; Hernandiz et al. 2012). Microorganisms form the main short-chained volatile fatty acid, i.e. acetic acid from the catabolization of various intermediate products.

TABLE 5 Total carbohydrate digested from each reactor

\begin{tabular}{lll}
\hline Experiment 1 & Influent $(\mathrm{g} / \mathrm{L})$ & Effluent $(\mathrm{g} / \mathrm{L})$ \\
\hline Dried leaves & 2.26 & 0.82 \\
Corn stove & 11.49 & 0.73 \\
Sugarcane bagasse & 15.06 & 0.69 \\
Control & 6.19 & 0.87 \\
\hline Experiment 2 & Influent $(\mathrm{g} / \mathrm{L})$ & Effluent $(\mathrm{g} / \mathrm{L})$ \\
\hline Dried leaves & 1.74 & 0.78 \\
Corn stover & 6.01 & 0.84 \\
Sugarcane bagasse & 18.11 & 0.72 \\
Control & 1.70 & 0.45 \\
\hline
\end{tabular}

The acetic acid concentration for both the experiments increased. Acetic acid accumulated in the reactor from Day 10 and onwards, and its concentration fluctuated throughout the retention period, as shown in Figure 5(b) and 5(d). The $\mathrm{pH}$ of the digester liquor can be lowered by the production of acetate and fatty acids. However, the ion bicarbonate equilibrium of the $\mathrm{CO}_{2}$ in the digester resists the variation of pH (Marchaim 2016).

Figure 6 illustrates the ethanol concentration and its trend throughout the digestion period. The intermediate product, ethanol, is produced in the acidogenesis phase of anaerobic digestion and accumulates in the reactor before being consumed by the microbial community in the next stage. Figures 6(a) and 6(b) indicated that the concentration of ethanol increased slowly. This happened because of the hydrolysis of complex organic molecules, whereas the fluctuations in trends show that the ethanol was converted into acetate and/or methane in the subsequent processes. Based on Figure 6 ethanol was detected in the range of 0.1-0.6 mg/L for both Experiment 1 and Experiment 2. 

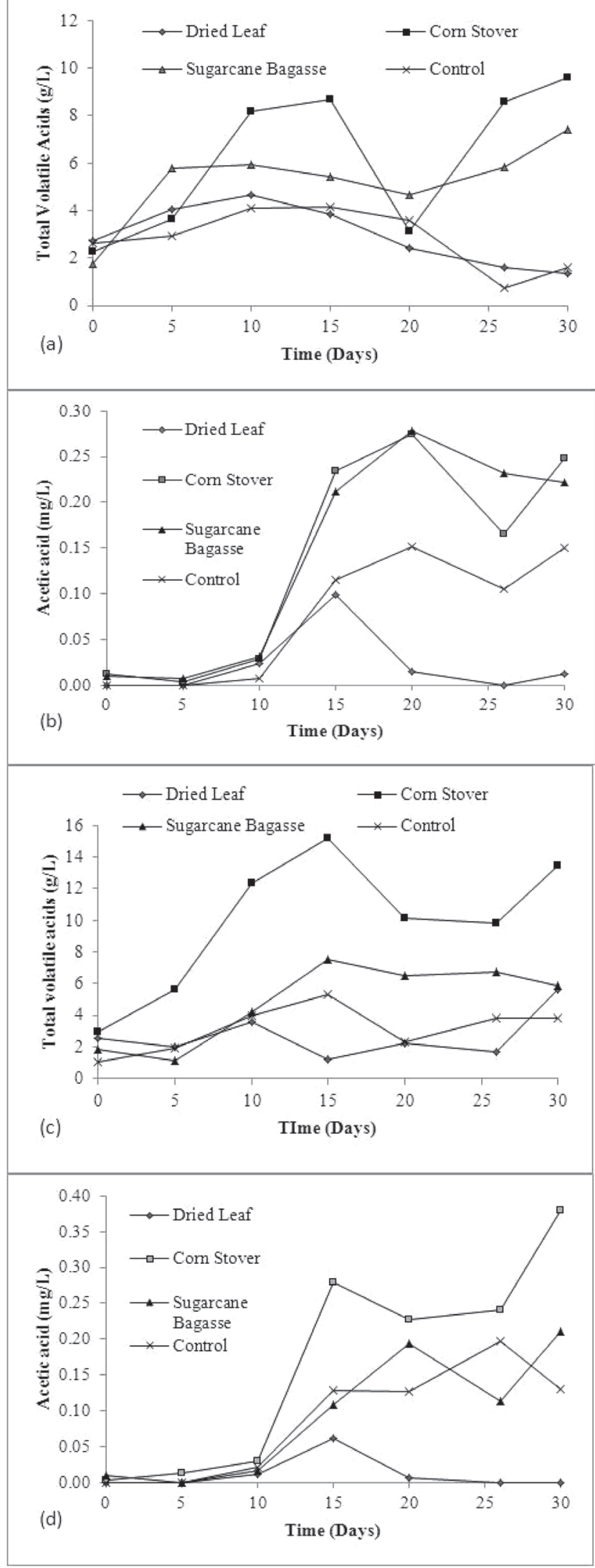

FIGURE 5 Total volatile acids and acetic acid concentration (a-b) Experiment 1 (c-d) Experiment 2
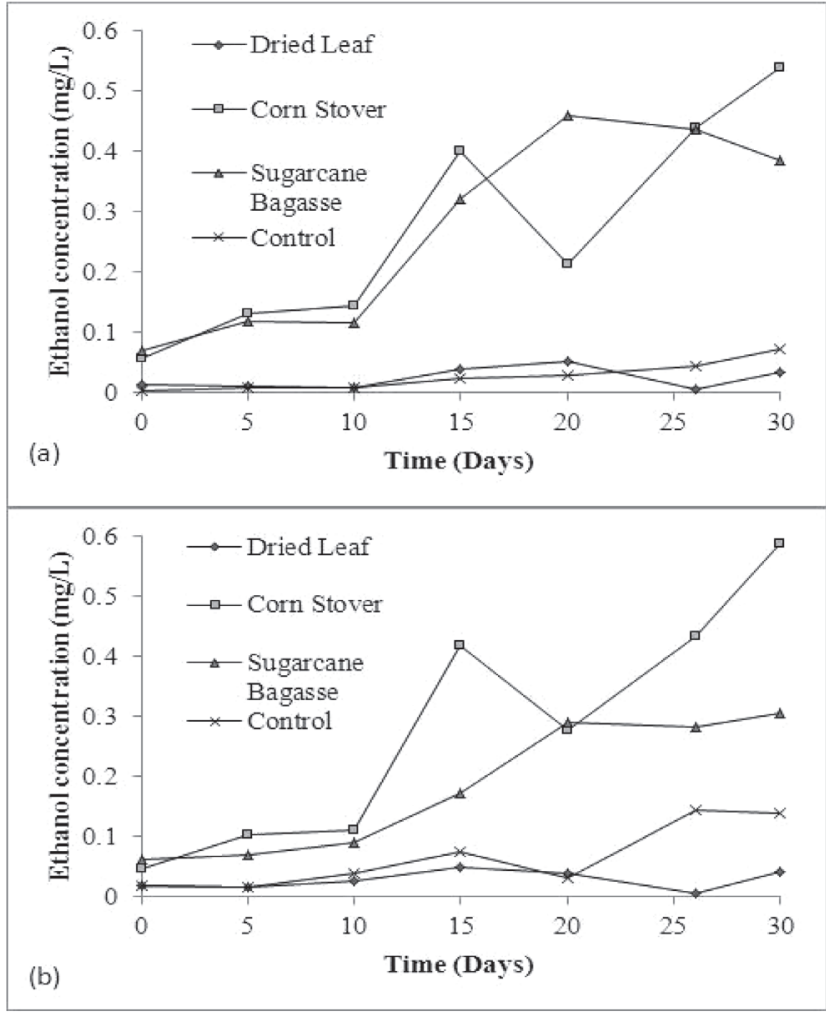

FIGURE 6 Ethanol concentration (a) Experiment 1 (b) Experiment 2

\section{BIOGAS PRODUCTION}

The rate of biogas generation and total biogas produced are a function of the organic fraction and biodegradability of the substrate (Macias-corral et al. 2008). Cumulative biogas production and methane composition were measured for both experiments. It can be seen in Figure 7 the biogas yield and production for Experiments 1 and 2 where Figures 7(a) and 7(c) show that the biogas yield fluctuated throughout the experiments. Meanwhile from Figure 7(b), the highest cumulative biogas production for Experiment 1 was observed with sugarcane bagasse $(20380 \mathrm{~mL})$, followed by corn stover $(19220 \mathrm{~mL})$, dried leaves $(12880 \mathrm{~mL})$ and the control $(9290$ $\mathrm{mL})$.

Similarly, for Experiment 2, the cumulative biogas production was the highest with sugarcane bagasse $(3400$ $\mathrm{mL})$, followed by the control $(2940 \mathrm{~mL})$, corn stover (2820 $\mathrm{mL})$ and dried leaves $(2620 \mathrm{~mL})$. It can be observed that with or without the addition of crude glycerol, the mixture of sugarcane bagasse and cow manure produced the highest quantity of biogas. In comparison, anaerobic digestion with the addition of crude glycerol resulted in higher biogas production than without the addition of crude glycerol. 

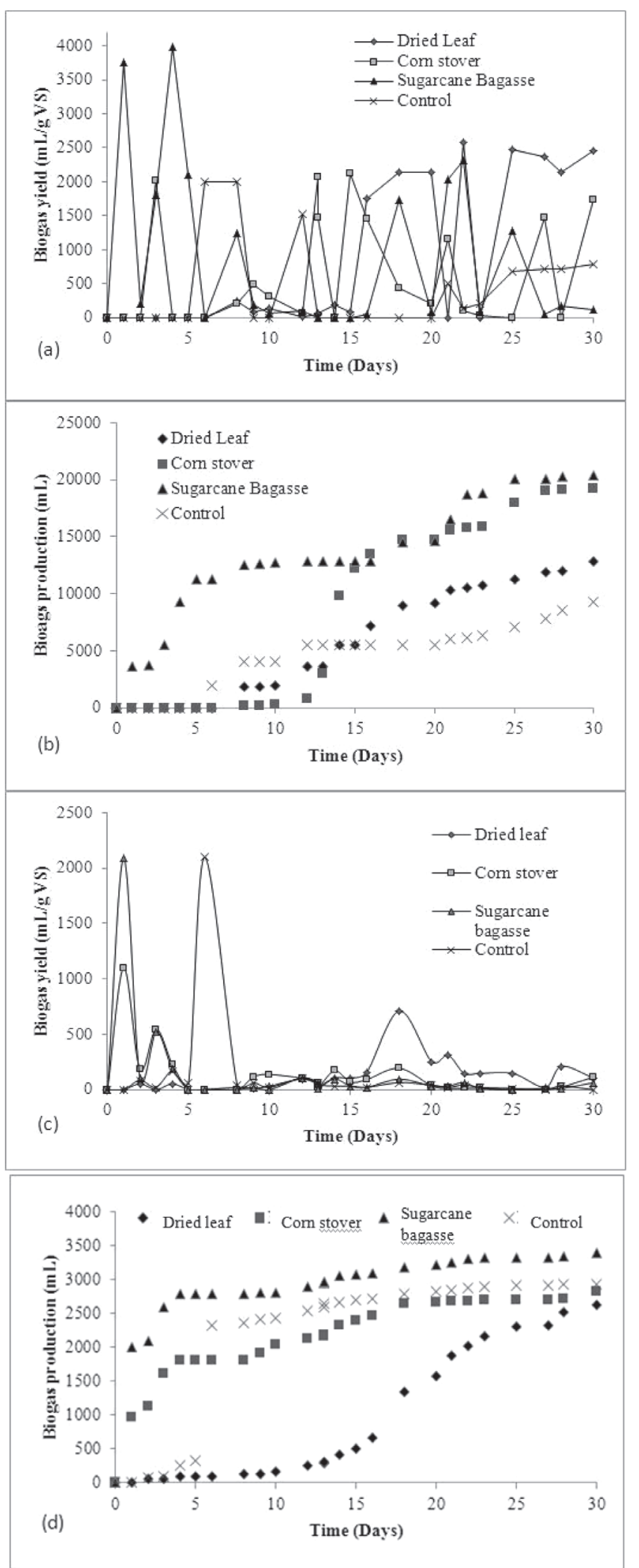

FIGURE 7. Biogas yield and production (a-b) Experiment 1 (c-d) Experiment 2

\section{METHANE PRODUCTION}

Methane gas was produced after Day 15 for the control reactor, whereas the other three reactors produced methane in the first two weeks of the experiment. The methane yield increased for the dried-leaves reactor as the retention time of the digestion increased. The highest methane yield (34.18\%) was observed in the dried-leaves reactor on the $25^{\text {th }}$ day in Experiment 1. However, the methane yield increased progressively as the experiment proceeded. Meanwhile daily biogas production in Experiment 2 was reasonably lower than in Experiment 1. The biogas composition for Experiment 2 was determined on the day on which gas collection was the highest. Table 6 displays the methane yield for Experiment 2. A similar trend as that for Experiment 1 was observed for Experiment 2, in which methane production slowly increased as digestion progressed. Methane content in the generated biogas had the highest value of $38.96 \mathrm{vol} \%$ for the driedleaves reactor on Day 25. The methane composition was slightly higher than that of carbon dioxide in the dried-leaves reactor; conversely, the corn stove and sugarcane bagasse reactors produced biogas with a lower methane yield.

Bari (1996) stated that the composition of methane and carbon dioxide in biogas may differ, depending on the type of raw materials and their ripeness, moisture level, temperature, microbial actions and the rate of loading of feedstock. However, many researchers have reported the improvement of biogas production (Fountoulakis 2010; A thanasoulia et al. 2014), from which it can be concluded that the enhancement of biogas production or methane yield largely depends on the type of feedstock used for digestion.

TABLE 6. Methane and carbon dioxide yield for Experiment 2

\begin{tabular}{lllll}
\hline Day & \multicolumn{4}{l}{ Methane yield (vol. \%) } \\
\cline { 2 - 5 } & Dried leaf & Corn stover & $\begin{array}{l}\text { Sugarcane } \\
\text { bagasse }\end{array}$ & Control \\
\hline 15 & 28.602 & 7.1646 & 15.4402 & 0 \\
20 & 43.272 & 14.1952 & 16.7389 & 13.8529 \\
25 & 38.961 & - & - & - \\
\hline \multicolumn{5}{c}{ Carbon dioxide yield (vol. \%) } \\
\hline 15 & 16.518 & 27.409 & 18.975 & 16.283 \\
20 & 24.717 & 30.577 & 24.394 & 21.075 \\
25 & 28.322 & - & - & - \\
\hline
\end{tabular}

Prolonging the retention period may increase the degradation of biomass (Jorgensen 2009) and eventually increase the yield of biogas production. Anaerobic codigestion does not essentially cause an increase in the methane yield but does increase the production of biogas (Kavuma 2013). Additionally, the oxidation state of the carbon content in the organic matter influences the ratio of $\mathrm{CH}_{4}$ and $\mathrm{CO}_{2}$, so that the more organic carbon is reduced, the more methane will be generated (Angelidaki et al. 2009). Moreover, Castrillón et al. (2013) stated that the methane 
yield can always be improved by supplementing the cattle manure and food waste co-substrates with a small quantity of glycerol because glycerol has better degradability than cattle manure. The composition of crude glycerol determines the maximum amount of glycerol that can be added to the anaerobic digestion.

\section{GLYCEROL AS CO-SUBSTRATE TO ENHANCE THE PRODUCTION} OF BIOGAS

Note that glycerol is used as a additional source of carbon and energy towards agro wastes sample by a large number of microorganisms that grow on a medium (cattle manure). Beside that used of glycerol as co-substrate capable : a) to maintain a $\mathrm{pH}$ of inoculum and sample within the methanogenesis range b) facilitate degradation of low biodegradability substrates c) contribute in decrease of the start-up period d) increase the biogas production (Ma et al. 2007). The metabolic pathways of anaerobic fermentation of glycerol can be occur by oxidative pathway. Viana et al. (2014) state that the oxidative route occur as following: a) dehydrogenating glycerol by the enzyme glycerol dehydrogenase b) dihydroxyacetone formation (after phosphorylation is mediated by the enzyme dihydroxyacetone kinase) c) formation of succinate d) formation propionate or to pyruvate by phosphoenolpyruvate. After formation of pyruvate, vary reactions occur depends on environmental conditions together with the enzymes that facilitate the reaction, i.e. from organism to organism, tend to form simpler compounds such as 2,3-butanediol, lactate, butyrate, ethanol, formate, acetate, hydrogen and carbon dioxide. Presence of multi-microorganisms through anaerobic co-digestion promotes the formation of formate, acetate, hydrogen and carbon dioxide (as bicarbonate) in the single bioreactor (Siles Lopez et al. 2009). Only if all of these compounds generate, hence these compounds can be converted directly to biogas and methane $\left(\mathrm{CH}_{4}\right)$.

\section{COMPARISON WITH PREVIOUS STUDY}

Castrillón et al. (2013) reported that $6 \% \mathrm{w} / \mathrm{w}$ was the optimal amount of crude glycerol to add to cattle manure for anaerobic digestion at $55^{\circ} \mathrm{C}$. Razaviarani \& Buchanan (2015) state that an improvement in VS and COD removal was observed with the improvement in the production of biogas and methane yield when biodiesel waste glycerol was added to municipal wastewater sludge in a quantity of up to $1.35 \% \mathrm{v} / \mathrm{v}$ and operated at $37^{\circ} \mathrm{C}$ for 20 days SRT. Similarly, Silvestre et al. (2015) found that the addition of $1 \% \mathrm{v} / \mathrm{v}$ glycerol to continuous sewage sludge and co-digestion at thermophilic and mesophilic temperature ranges caused an increase of $148 \%$ in the methane yield, and glycerol stimulated biomass activity specific to $\mathrm{H}_{2}$ and propionate. On the other hand, when $2 \% \mathrm{v} / \mathrm{v}$ glycerol was anaerobically digested with mixed sewage sludge for 200 days, and it was discovered that $2 \% \mathrm{v} / \mathrm{v}$ glycerol feeding in a continuous operation enhanced organic loading by $70 \%$ and increased the production of methane by $50 \%$. Additionally, the half-maximal inhibitory glycerol concentration was $1.01 \mathrm{~g} \mathrm{VS}^{-1}$. Another study proved that biogas production was increased by $40 \%$ when $4 \%$ glycerol was co-digested with pig manure in semi-continuous stirred tank reactors for 200 days. Comparatively, in the current study, $1 \% \mathrm{v} / \mathrm{v}$ glycerol addition to the anaerobic digestion of agricultural wastes and cattle manure showed significant improvement in the $\mathrm{C} / \mathrm{N}$ ratio in the feed, and enhancement in the biogas production, as well as COD removal up to $56 \%$, was achieved. Therefore, it can be concluded from past studies and also from the present study that the addition of crude glycerol indeed boosts biogas production and the methane yield in the anaerobic digestion process. However, it is vital to maintain other operational parameters appropriately for an effective anaerobic digester operation.

\section{CONCLUSION}

About $96 \%$ of total carbohydrate digested in the bioreactor by co-digestion of sugarcane bagasse to become bio-liquid, biogas and solid products. Value of COD removals from Experiment 2 higher than Experiment 1 for all of agro wastes samples. Besides formation of total volatile acids and acetic acid in Experiment 2 (without glycerol) higher than Experiment 1 due to sufficient amount of methanogen and retention time for anaerobic co-digestion (30 days). Meanwhile as in the Experiment 1 there was additional carbon source (glycerol) that caused extra in total carbohydrate. Therefore a additional retention time for anaerobic codigestion required for sufficient methanogen activitiy. However the objective of this study was achieved when 20380 $\mathrm{mL}$ biogas obtained by anaerobic co-digestion of sugarcane bagasse sample in Experiment 1 (with glycerol) considered higher than in Experiment 2 (without glycerol) which result in $3400 \mathrm{~mL}$. Present study proves there was improvement in biogas production in co-digestion of agro wastes with cattle manure by using glycerol as co-substrate. biogas from sugarcane bagasse. Study of retention time for anaerobic co-digestion and optimization of experiment is suggested to obtain the maximum yield of biogas.

\section{ACKNOWLEDGEMENT}

The authors acknowledge the Ministry of Education of Malaysia (MOE) under GSP/1/2015/TK01/UKM/01/1 and Universiti Kebangsaan Malaysia (UKM) under DIP-20170021.

\section{REFERENCES}

Abbasi-Guendouz, A. 2012. Total solids content drives high solid anaerobic digestion via mass transfer limitation. Bioresource Technology 111: 55-61.

Ahring, B.K., Sandberg, M. \& Angelidaki, I. 1995. Volatile fatty acids as indicators of process imbalance in anaerobic digestors. Applied Microbiology and Biotechnology 43(3): 559-565. 
Al-Masri, M.R. 2011. Changes in biogas production due to different ratios of some animal and agricultural wastes. Bioresource Technology 77(1): 97-100.

Almeida, J.R.M., Favaro, L.C.L. \& Quiriro, B.F. 2012. Biodiesel biorefinery opportunity and challenges for microbial production of fuels and chemicals from glycerol waste. Biotechnology for Biofuels 5: 1-48.

Angelidaki, I. 2009. Defining the biomethane potential (BMP) of solid organic wastes and energy crops: A proposed protocol for batch assays. Water Science \& Technology 59(5): 927-934.

Anitha, M., Kamarudin, S.K. \& Kofli, N.T. 2016 The potential of glycerol as a value-added commodity. Chemical Engineering Journal 295: 119-130.

Astals, S., Nolla-Ardevol, V. \& Mata-Alvarez, J. 2012. Anaerobic co-digestion of pig manure and crude glycerol at mesophilic conditions: biogas and digestate. Bioresource Technology 110: 63-70

Athanasoulia, E., Melidis, P. \& Aivasidis, A. 2014. Codigestion of sewage sludge and crude glycerol from biodiesel production. Renewable Energy 62: 73-78.

Ayoub, M. \& Abdullah, A.Z. 2012. Critical review on the current scenario and significance of crude glycerol resulting from biodiesel industry towards more sustainable renewable energy industry. Renewable and Sustainable Energy Reviews 16(5): 2671-2686.

Baba, Y. 2013. Anaerobic digestion of crude glycerol from biodiesel manufacturing using a large-scale pilot plant: Methane production and application of digested sludge as fertilizer. Bioresource Technology 140: 342-348.

Bari, S. 1996. Effect of carbon dioxide on the performance of biogas/diesel duel-fuel engine. Renewable Energy 9(1-4): 1007-1010.

Berhard, D. 2013. Process monitoring in biogas plants. http://www.ieabioenergy.com/publications/processmonitoring-in-biogas-plants/ [14 May 2018].

Bournay, L. 2005. New heterogeneous process for biodiesel production: A way to improve the quality and the value of the crude glycerin produced by biodiesel plants. Catalysis Today, 106(1-4):190-192.

Castrillón, L. 2013. Thermophilic co-digestion of cattle manure and food waste supplemented with crude glycerin in induced bed reactor (IBR). Bioresource Technology 136: 73-77.

E1759-08, A. 2008. Standard test method for determination of total solids in biomass. https://www.astm.org/Standards/ E1756.htm [17 May 2017].

E897-88, A. 2004. Standard test method for volatile matter in the analysis sample of refuse-derived fuel. https://www. astm.org/Standards/E897 [17 May 2017].

Fernando, S. 2007. Glycerol based automotive fuels from future biorefineries. Fuel 86(17-18): 2806-2809.

Fountoulakis, M.S., Petousi, I. \& Manios, T. 2010. Codigestion of sewage sludge with glycerol to boost biogas production. Waste Management 30(10): 1849-1853.

Gavala, H.N., Angelidaki, I. \& Ahring, B.K. 2003. Kinectic and modelling of anerobic digestion process. Advances in Biochemical Engineering/Biotechnology 81(2003): 57-93.

Goswami, D.Y. \& Kreith, F. 2007. Handbook of energy efficiency and renewable energy. CRS Press. 1560. 9781420003482.

Hazimah, A.H., Ooi, T.L. \& Salmiah, A. 2003. Recovery of glycerol ans diglycerol from glycerol pitch. Journal Oil Palm Research 15(1): 1-5.

Hernandiz, V.M. 2012. Monitoning anaerobic digestion of animal slurry during inhibition and revovery phases, in Departmento de ciencia animal. Universidad politecnica de valencia. https://riunet.upv.es/handle/10251/18069 [15 June 2018].

Jorgensen, P.J. Biogas-Green Energy. 20093 August 2015; Available from: http://scitech.au.dk/. [2 May 2018].

Kavuma, C. 2013. Variation of methane and carbon dioxide yield in a biogas plant, in Department of Energy Technlogy. Royal Institute of Technology: Stockhelm, Sweden. http://www.diva-portal.org/smash/ get/diva2:604559/FULLTEXT02.pdf [30 June 2018].

Liu, L. 2015. Anaerobic co-digestion of animal manure and wheat straw for optimized biogas production by the addition of magnetite and zeolite. Energy Conversion and Management 97: 132-139.

Ma, J., Wambeke, M.V., Carballa, M. \& Verstraete, W. 2007. Improvement of the anaerobic treatment of potato processing wastewater in a UASB reactor by co-digestion with glycerol. Biotechnology Letter 3: 861-867.

Macias-Corral, M. 2008. Anaerobic digestion of municipal solid waste and agricultural waste and the effect of co-digestion with dairy cow manure. Bioresource Technology 99(17): 8288-93.

Madzaki, H., Ghani, W.A.K.W.A., Shean, Y.T.C. 2018. Carbon dioxide adsorption on activated karbon hydrothermally treated and impregnated with metal oxides. Jurnal Kejuruteraan 30(1): 31-38

Mata-Alvarez, J. 2003. Fundamentals of the anaerobic digestion process, in Biomethanization of the organic fraction of municipal solid wastes. IWA Publishing: Cornwall, UK. p. 323.

Mata-Alvarez, J. 2011. Codigestion of solid wastes: a review of its uses and perspectives including modelling. Critical Reviews in Biotechnology 31(2): 99-111.

Marchaim, U. 1992. Biogas processes in sustainable development. MIGAL Galilee Technological Centre Kiryat Shmona: Israel. http://agrienvarchive.ca/ bioenergy/download/Marchaim biogas processes fao 1992.pdf ISBN 92-5-103126-6.

Mital, K.M. 1997. Biogas Systems: Policies, Progress, Prospects. New Delhi, India: New Age International (P) Ltd. 278.

Ramadhas, A.S., Jayaraj, S. \& Muraleedharan, C. 2005. Biodiesel production from high FFA rubber seed oil. Fuel 84(4): 335-40.

Razaviarani, V. \& Buchanan, I.D. 2016. Anaerobic codigestion of biodiesel waste glycerin with municipal wastewater sludge: microbial community structure 
dynamics and reactor performance. Bioresource Technology 182: 8-17.

Rivero, M., Solera, R. \& Perez, M. 2014. Anaerobic mesophilic co-digestion of sewage sludge with glycerol: Enhanced biohydrogen production. International Journal of Hydrogen Energy 39(6): 2481-2488.

Robra, S. 2010. Generation of biogas using crude glycerin from biodiesel production as a supplement to cattle slurry. Biomass and Bioenergy 34(9): 1330-5.

Siles Lopez, J.A. 2009. Anaerobic digestion of glycerol derived from biodiesel manufacturing. Bioresource Technology 100(23): 5609-15.

Silvestre, G., Fernández, B. \& Bonmatí, A. 2015. Addition of crude glycerine as strategy to balance the $\mathrm{C} / \mathrm{N}$ ratio on sewage sludge thermophilic and mesophilic anaerobic co-digestion. Bioresource Technology 193(2015): $377-$ 385.

Strik, D.P.B.T.B., Domnanovich, A.M., \& Holubar, P. 2006. A $\mathrm{pH}$-based control of ammonia in biogas during anaerobic digestion of artificial pig manure and maize silage. Process Biochemistry 41(6): 1235-1238.

Tokumoto, H. \& Kashiwagi, M. 2012. Changes in dominant fermentation type during anaerobic digestion of highloading glycerol with slight glucose content. Bioresource Technology 126 (2012):13-7.

United Nation Environmet Program. 2011. Global Partnership on Waste Management, in Waste Agricultural Biomass to Energy (WAB2E). Division of Technology, Industry and Economics, International Environmental Technology Centre.

Viana , M.B., Freitas, A.V., Leitão, R.C., Pinto, G.A.S. \& Santaella, S.T. 2014. Anaerobic digestion of crude glycerol: a review. Environmental Technology Reviews 1(1): $81-92$

Watanabe, R. 2013. Enhancing methane production during the anaerobic digestion of crude glycerol using Japanese cedar charcoal. Bioresouce Technology 150(2013): 387-92.

Water Environment Federation. 1999. Standard methods for the examination of water and wastewater. American
Public Heath Association: Washington, DC. https://www. standardmethods.org/

Wei, S. 2014. Psychrophilic anaerobic co-digestion of highland barley straw with two animal manures at high altitude for enhancing biogas production. Energy Conversion and Management 88(2014): 40-48.

Yazdani, S.S. \& Gonzalez, R. 2007. Anaerobic fermentation of glycerol: a path to economic viability for the biofuels industry. Current Opinion in Biotechnology 18(3): 213219.

Yuzir, A., Chelliapan, S. \& Sallis, P.J. 2012. Impact of herbicide (RS)-MCPP on an anaerobic membrane bioreactor performance under different $\mathrm{COD} /$ nitrate ratios. Bioresource Technology 109: 31-37.

Zhou, P., Elbeshbishy, E. \& Nakhla, G. 2013. Optimization of biological hydrogen production for anaerobic codigestion of food waste and wastewater biosolids. Bioresouce Technology 130: 710-8.

*Siti Kartom Kamarudin

Fuel Cell Institute,

Universiti Kebangsaan Malaysia, Malaysia

Department of Chemical Engineering \& Process, Faculty of Engineering \& Built Environment, Universiti Kebangsaan Malaysia, Malaysia

Anitha a/l Muniandy, Noor Shahirah Shamsul, Hisham Tan Kofli

Department of Chemical Engineering \& Process , Faculty of Engineering \& Built Environment,

Universiti Kebangsaan Malaysia, Malaysia

*Corresponding author; email: ctie@ukm.edu.my

Received date: $9^{\text {th }}$ April 2018

Accepted date: $13^{\text {th }}$ September 2018

Online First date: $31^{\text {st }}$ September 2018

Published date: $1^{\text {st }}$ November 2018 